\section{REVIEW OF GENERAL PRACTICE}

\section{EVIDENCE INVITED}

A special committee of the B.M.A.-the General Practice Review Committee-is carrying out a large survey of general practice. It would like to hear evidence from general practitioners. The Secretary of the B.M.A. therefore invites general practitioners to submit to him a memorandum on matters about which they wish to give evidence.

\section{Main Inquiries}

The committee is also carrying out two large-scale inquiries in order to obtain information. The secretary of the committee is travelling round the country studying at first hand about 200 practices selected by a random method. Questionaries are also being sent to all general practitioners. The investigation is under expert statistical supervision.

\section{NEW CERTIFICATE OF INCAPACITY}

The B.M.A. has produced a certificate of incapacity based on the certificate E.D.652, which was previously supplied by the Ministry of Labour and National Service. The certificate is designed for use when a patient requests evidence of incapacity for presentation to his employer or for a similar purpose.

The new certificate is made up in books of 50, and supplies may be obtained on application to the Finance and Business Officer of the Association. In order to cover the cost of paper, printing, and postage, 1s. $6 \mathrm{~d}$. is being charged for each book of 50 certificates.

\section{AUXILIARIES' HIGHER PAY \\ INDUSTRIAL COURT AWARD}

The Industrial Court has awarded that the present salary scales of medical auxiliaries shall be increased by $£ 50$ at all points as from April 1.

The medical auxiliaries concerned are almoners, occupational therapists, orthoptists, physiotherapists, psychiatric social workers, remedial gymnasts, speech therapists, and therapeutic dietitians.

The Court noted that the present salaries had been in operation since 1948 or earlier-in some cases since 1946 The claim was negotiated through the Whitley Council, both sides of which agreed that the present salaries needed revision.

\section{TRADE UNION MEMBERSHIP}

The following is a list of local authorities which are understood to require employees to be members of a trade union or other organization:

County Council.-Durham.

Metropolitan Borough Councils.-Bethnal Green, Fulham, Hackney, Poplar, Southwark, Stoke Newington.

Non-County Borough Councils.-Crewe, Dartford.

Urban District Councils.-Droylsden, Houghton-le-Spring, Huyton-with-Roby.

Correction.-In our report of the Annual Representative Meeting (Supplement, June 23, p. 253) we erroneously stated at p. 281 that Dr. A. V. J. Russell moved the motion on "The Trade Union Issue." In fact it was moved by Dr. R. W. L. Pearson (Birkenhead and Wirral).

\section{Heard at Headquarters}

\section{The Credulous Iconoclast}

The spate of books about G.B.S. which have followed his death have shown what an enemy he was to pretensions and shams in medicine as in other spheres. But on reading the book by Miss Patch, who was his secretary for 30 years, one is startled to find how credulous was this iconoclastic philosopher when it came to a question of treatment of himself. Anything, however preposterous, was welcomed by him so long as it had not anything to do with the orthodox medical profession. He was treated five or six times by Abrams's box, a device which many years ago had a great vogue in the United States. He had heard from a Scandinavian who claimed to be able to treat all ailments by natural methods. Said Shaw, "There is no harm in finding out what this naturopath has to say at my expense." Miss Patch tells us that Shaw's most fantastic "cure" was one which he passed on, with perfect seriousness, to an actress of his acquaintance for loss of sight. His idea was that loss of sight which was due to shock cured itself by means of another shock, and he gave explicit directions how that shock was to be administered. It appears that Shaw, who left a third of a million, wrote to the National Health Service authorities inquiring how he stood for registration under the Act, as he wished to have a "national" doctor in case he was unable to afford a private one.

\section{Health and Beauty}

From a doctor's letter: "I have been asked for many things under the National Health scheme, but here is the latest request. A woman put down her medical card and demanded to have her ears pierced for ear-rings. I declined."

\section{Sport Section}

A doctor writes to say that when he answered his telephone the other day a voice said: "Oh, doctor, this is A. B. speaking. When my mother comes to surgery this morning will you ask her to wash my white flannels to-day ?" The doctor did not commit his reply to paper, but apparently the man's mother did not turn up.

\section{The Spa Handbook}

Many messages of appreciation have been received of the B.M.A. handbook on The Spa in Medical Practice. In particular the British Spas Federation, believing that the handbook will be useful to all concerned with the treatment of patients at spas, has expressed the hope that all doctors will obtain a copy. In order to encourage them to do so the Federation has generously offered to defray the cost of a second printing for free distribution. The offer has been gladly accepted, and copies of the lrandbook are available to members of the profession free of charge. They are obtainable on application to the Publishing Manager at B.M.A. House.

\section{Something Wrong}

A doctor writes that the following conversation was overheard recently in his surgery waiting-room :

1st Old Gentleman: Hallo! What's wrong with you ?

2nd Old Gentleman: Why, nothing.

1st Old Gentleman: Don't be silly. There must be something wrong or you wouldn't be here.

2nd Old Gentleman: Oh, I just like to come occasionally for a bottle of medicine. After all, it's all free.

He asks who is responsible for this attitude of mind-the Minister or the profession? 